\title{
FIRST FINDINGS ON THE SEROEPIDEMIOLOGY OF HUMAN PARAGONIMOSIS AT THE ANTI-TUBERCULOSIS CENTRE OF DIVO, RepUblic of IVory CoAst (West Africa)
}

\author{
AKA N.A.***, ASSOUMOU A.**, ADOUBRYNK. D.***, DOMOUA K.***, KOUADIO F.**, MOYOU-SOMO R. ****, \\ NAKAMURA-UCHIYAMA F. *****, NAWA Y.*****, RONDELAUD D.* \& DREYFUSS G.*
}

\section{Summary :}

An epidemiological study was carried out in 2004-2005 at the anti-tuberculosis centre of Divo (lvory Coast) to collect sera from patients who consulted for tuberculosis suspicion and to estimate the seroprevalence of human paragonimosis in the context of a systematic screening. No Paragonimus egg was found in the stools and/or sputa of the 167 persons investigated. In contrast, 41 sera were ascertained with antibodies against Paragonimus africanus using ELISA testing. As the optical density (OD) values related to seropositive findings were found under 0.6 (the minimal $O D$ to detect an active paragonimosis), the above antibody titres might originate from patients in chronic or in convalescent stages, or might result of cross reactions with trematodes. Concomitantly, dissection of local crabs (Callinectes marginatus) demonstrated the presence of Paragonimus metacercariae in six out of 34 examined. The parasite burdens in crabs ranged from two to 35 cysts with a mean diameter of 302 um. In Ivory Coast, the locality of Divo must be considered an at-risk zone in reason of the presence of anti-Paragonimus antibodies in several human sera and the presence of infected crabs at the local market.

KEY WORDS : Callinectes marginatus, Africa, Ivory Coast, metacercaria, paragonimosis, seroprevalence.

MOTS CLÉS : Callinectes marginatus, Afrique, Côte d'lvoire, métacercaire, paragonimose, séroprévalence.

\section{INTRODUCTION}

H uman paragonimosis, also known as endemic haemoptysis, is a food-borne parasitosis, caused by lung flukes of Paragonimus genus (World Health Organization, 1995). This disease poses a real public health problem in some parts of the world. In fact, 200 million people are exposed to this

\footnotetext{
* UPRES EA n 3174, Faculties of Medicine and Pharmacy, 87025 Limoges, France.

** Laboratory of Parasitology, Faculty of Medicine, BP V 166, Abidjan, Ivory Coast.

*:** Department of Pneumophtisiology, Treichville University Hospital, BP V 13, Abidjan, Ivory Coast.

**** Institute of Medical Research and Study of Medicinal Plants/Medical Research Centre, BP 193, Yaounde, Cameroon.

***:**: Laboratory of Parasitology, Faculty of Medicine of Miyazaki, 5200 Kiyotake, Japan.

Correspondence: Daniel Rondelaud.

Tel.: +33 (0)5 55435833 - Fax: +33 (0)5 55435893 .

E-mail: daniel.rondelaud@unilim.fr
}

Résumé : Premiers documents sur la SÉRoÉPidémiOlogie de la PARAGONIMOSE humaine Au CENTRE ANTI-TUBERCULEUX DE Divo, République de Côte d'IVoire (AFrique de l'Ouest)

Une étude épidémiologique a été réalisée en 2004-2005 au centre anti-tuberculeux de Divo (Côte d'lvoire) pour recueillir les sérums de patients qui consultaient pour une suspicion de tuberculose et les analyser en utilisant la technique ELISA afin de déterminer la séroprévalence de la paragonimose humaine dans le contexte d'un dépistage systématique. Aucun œuf de Paragonimus n'a été trouvé dans les selles ou les expectorations des 167 personnes examinées. Par contre, des anticorps contre Paragonimus africanus ont été identifiés dans les sérums de 41 patients. Comme les valeurs notées pour la densité optique des échantillons identifiés positifs étaient au-dessous de 0,6 lla valeur seuil minimale en rapport avec une paragonimose active), ces anticorps pourraient provenir de patients en phase chronique ou en convalescence, ou les résultats pourraient être en rapport avec la présence de trématodes. Par ailleurs, la dissection des crabes locaux (Callinectes marginatus) a montré la présence de métacercaires spécifiques de Paragonimus chez six crustacés (sur les 34 examinés). Les charges parasitaires se distribuaient entre deux et 35 métacercaires par crabe tandis que le diamètre moyen des kystes était de $302 \mu \mathrm{m}$. En Côte d'lvoire, la localité de Divo doit être considérée comme une zone à risque en raison de la présence d'anticorps anti-P. africanus dans le sérum de certains sujets et surtout la présence de crabes infestés sur le marché local. 


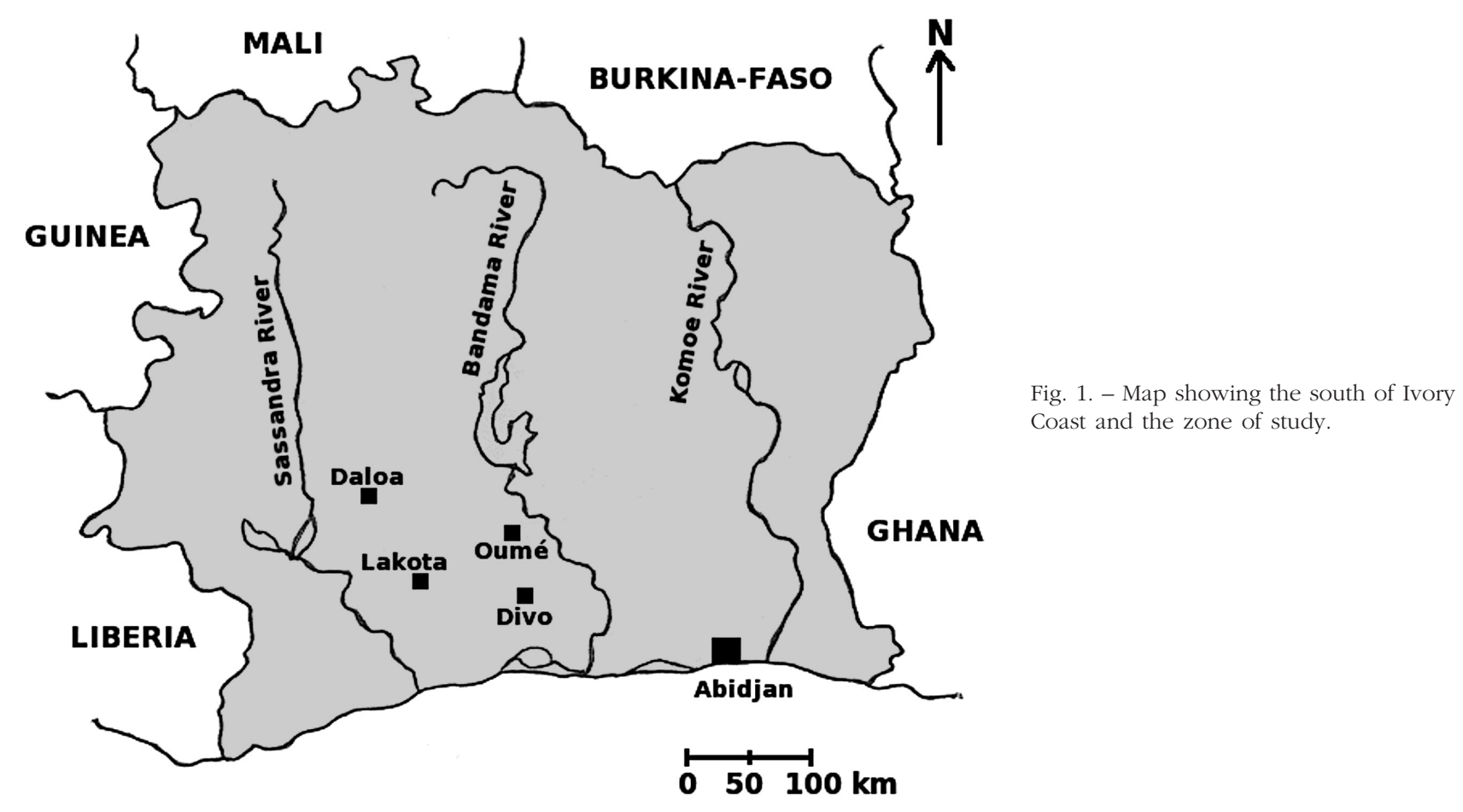

was the most used technical practice to find Paragonimus eggs. ELISA testing was still little used, even if this method is essential to detect acute and chronic cases of paragonimosis when eggs are absent in stools and expectorations. As no systematic detection of this parasitosis using serology was still carried out in Ivory Coast, it was interesting to study the conditions under which such a screening might be conducted. To answer this question, a field study was made from July 2004 to January 2005 at the anti-tuberculosis centre of Divo (Ivory Coast) to collect sera from patients consulting for tuberculosis suspicion and to analyze them in a Japanese laboratory specialized in serological detection of paragonimosis. A complementary study was also carried out on local river crabs to search metacercariae of Paragonimus spp.

\section{MATERIALS AND METHODS}

\section{PATIENTS STUDIED}

T The centre of Divo $\left(5^{\circ} 48^{\prime} \mathrm{N}, 5^{\circ} 15^{\prime} \mathrm{W}\right)$ is located at $200 \mathrm{~km}$ from Abidjan (Fig. 1). The choice of this centre is based on the fact that every year, a mean of 1,000 persons were examined for tuberculosis. Among them, 500 to 600 patients were Mycobacterium tuberculosis-negative in their sputa and several persons have sometimes received an anti-tuberculosis treatment when a chronic pneumonia was noted (unpublished data). The population of the Divo district comprised 534,644 persons (national census of 1998) and is composed of Dida-, Godie- and Ega-speaking ethnic groups. These medical investigations were made with the agreement of the Ivorian Ministry of Public Health in December 2002.

206 persons between July 2004 and January 2005 were contacted during their medical consultation at the antituberculosis centre of Divo. The purpose and methodology of the survey were explained to them and, finally, 89 men and 78 women had given their informed consent to participate to a paragonimosis survey. Their age was less than 30 years (58 persons), between 30 and 60 years (92), and more than 60 years (17). During examination, each patient was questioned about its past or recent symptoms and its crustacean-eating habits. Five $\mathrm{ml}$ of venous blood were collected from each patient and centrifuged during $2 \mathrm{~min}$ at $1,500 \mathrm{rpm}$ before the storage of each serum at $-20^{\circ} \mathrm{C}$. Stool and sputum samples were also collected to detect the presence of Paragonimus eggs under a microscope on direct examination.

\section{SEROLOGICAL TESTS}

The sera collected from patients were analyzed at the Laboratory of Parasitology, Faculty of Medicine of Miyazaki Kitoyake (Japan). Microplate ELISA tests using Paragonimus africanus antigens were carried out on their sera. Three lyophilized adult worms originating from Cameroon were homogenized in $2 \mathrm{ml}$ PBS before being centrifuged at $15,000 \mathrm{rpm}\left(4^{\circ} \mathrm{C}\right)$ for one hour. After collection of the supernatant, the total protein content was determined using a standard curve obtai- 
ned by a serial dilution of known concentration of bovine serum albumine. The sensitivity of ELISA tests using $P$. africanus antigens was calculated using three positive sera from Africans patients having Paragonimus eggs in their sputa and was $100 \%$. In the same way, the specificity using negative sera of 30 healthy patients was $97 \%$.

Due to the possibility of cross reactions with other trematodoses which were usually found in Ivory Coast, antibody titres against Fasciola hepatica (in the case of fasciolosis) and Schistosoma japonicum (in the case of schistosomosis) antigens were also investigated. These antigens were kindly provided by the Laboratory of Parasitology, Faculty of Medicine of Miyazaki Kitoyake. All antigens were kept at $-20^{\circ} \mathrm{C}$ until their use.

Three ELISA tests (one for each antigen) were realized for each patient. First, the antigen concentration of each parasite was adjusted at $10 \mu \mathrm{g} / \mathrm{ml}$ by diluting it with a carbonate-bicarbonate buffer, $\mathrm{pH}$ 9.6. $50 \mu \mathrm{l}$ of this antigen solution were placed in each well and the plate was incubated overnight at $4^{\circ} \mathrm{C}$ before being washed three times with $200 \mu \mathrm{l}$ of PBS containing $0.05 \%$ Tween-20. Secondly, $200 \mu \mathrm{l}$ of $0.1 \%$ casein in PBS were added to each well and the plate was again kept two hours at room temperature to block non-specific binding sites. Thirdly, the serum of each patient was diluted to $1: 500$ with $0.1 \%$ casein/PBS and $50 \mu \mathrm{l}$ of this dilution were deposited in each well. The plate was then incubated one hour at $37^{\circ} \mathrm{C}$ before being washed as above. Fourthly, $50 \mu \mathrm{l}$ of horseradish peroxydase-labelled rabbit anti-human IgG ( $\mu$-chain specific) (Dako Group, Troy, Michigan, USA) diluted to 1:2000 in PBS, pH 7.4 were added to each well and the microplate was again incubated 1 hour at $37^{\circ} \mathrm{C}$ before being washed as above. Lastly, $50 \mu \mathrm{l}$ of ABTSsubstrate solution (Kirkgaard and Perry Laboratories, Gaithersburg, Maryland, USA) were added to each well. The plate was incubated $10 \mathrm{~min}$ at $37^{\circ} \mathrm{C}$ and the reaction was stopped by adding $50 \mu \mathrm{l}$ of $1 \%$ SDS to each well. The optical density (OD) of each well was read using an EL $\times 800$ Universal Microplate Reader (Bunkyo-Ku, Tokyo, Japan) at $405 \mathrm{~nm}$.

The negative cut-off values were calculated using sera originating from 29 healthy persons without trematode infection. Based on the following formula: mean OD + 3 standard deviations, the values were $0.088,0.20$ and 0.41 , respectively, for $P$. africanus, S. japonicum and $F$. hepatica antigens.

\section{INVESTIGATIONS IN CRABS}

A total of 34 crabs (Callinectes marginatus) were bought at the local market of Divo. Soft masses of every crustacean were then crushed in a meat mill before being placed in one litre of tap water. After agitation for $3 \mathrm{~min}$, the mixture was placed for 10 min to deposit sediment. This process was repeated several times until the supernatant became transparent and the sediment was subsequently collected for examination under a microscope.

\section{RESULTS}

\section{PATIENT EXAMINATION}

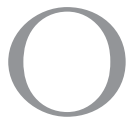
ut of the 167 persons, cough was noted in 159 patients (95\%) and chest pain in $133(79 \%)$. One hundred and five persons (62\%) complained of weight loss and $91(54 \%)$ of fever. A part from 11 persons $(6 \%)$, the general health status was good. 44 patients $(26.3 \%)$ had a pulmonary condensation syndrome and eight ( $4.7 \%$ ) showed a fluid collection syndrome. The history of 79 patients ( 46 men, 33 women) included crab/crayfish-eating habits. No Paragonimus egg was found in their stool and sputum samples.

Out of the 167 sera tested against Paragonimus antigens, 60 had their ODs above 0.09 (data not shown). These 60 sera were also analyzed to detect antibodies against $F$. hepatica and $S$. japonicum antigens. Among them, 19 had positive cut-off values for either of both above parasites so that they were excluded. In the other 41 sera, cut-off values for F. hepatica and S. japonicum were negative. Figure 2 shows that cut-off values of Paragonimus ranged between 0.09 and 0.20 for 38 patients and over 0.20 for the three others so that patients with greater than 0.09 ODs were suspected to be infected with Paragonimus spp. Clinically, 12 were also affected by tuberculosis and 31 were known to regularly eat freshwater crabs and/or help for crab cooking.

\section{INVESTIGATIONS IN CRABS}

Out of the 34 crustaceans studied, six C. marginatus (17.6 \%) harboured Paragonimus-specific metacercariae, as described by Blair et al. (1999). The parasite burden ranged from two to 35 cysts per crab and their mean diameter was $302 \mu \mathrm{m}$ (SD: $11.5 \mu \mathrm{m})$. The mean thickness of metacercaria wall was $17 \mu \mathrm{m}$.

\section{DISCUSSION}

The results reported in the present study confirm the low sensitivity of examinations performed on stools and/or sputa to detect Paragonimus eggs, as already documented by other authors (Mukae et al., 2001; Moyou-Somo et al., 2003). This fact might be explained by the irregularity of parasite egg-laying 


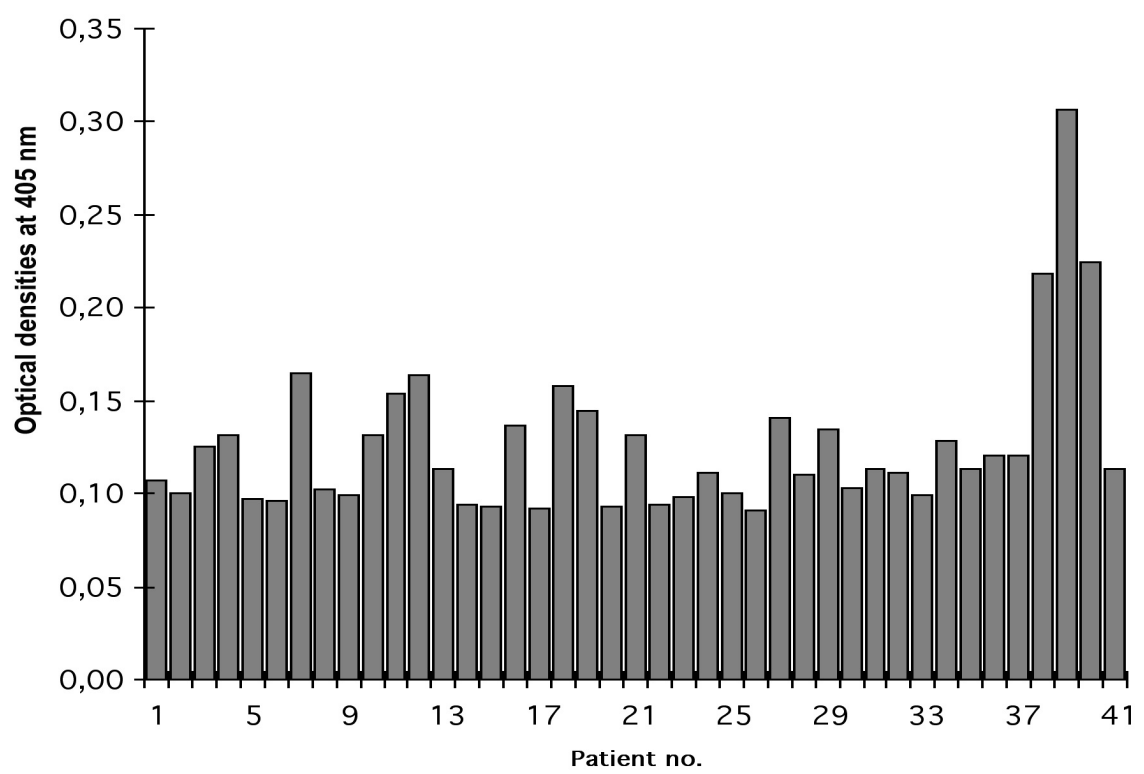

Fig. 2. - Optical densities of antibodies against $P$. africanus antigens in the sera of 41 patients.

over time. In spite of the absence of Paragonimus egg, the use of serology against $P$. africanus antigens demonstrated the presence of higher than 0.09 ODs in the sera of 41 patients (frequency, $24.5 \%$ ). This percentage is slightly lower than that (31.2\%) reported by Ripert et al. (1981) in Cameroon but it is difficult to compare these results, as these last authors had considered greater than 0.12 ODs as positive for paragonimosis. As the minimal OD for considering a human serum as positive for Paragonimus antigens, whatever species, is currently estimated at 0.6, particularly when the disease is in active stage, two likely complementary hypotheses to interpret results found in the 41 patients might be proposed. The first was to consider that several of these patients would be in chronic or in convalescent stages and this assumption is supported by the past history of paragonimosis-evocating symptoms found for these persons. In addition, ectopic infection cases cannot be excluded, as hypothesized by Cho et al. (1983) for serological results they have obtained in Korea. The second assumption would be the possibility of cross reactions between $P$. africanus and trematodes other than F. bepatica and/or S. japonicum. As these parasites did not exist in Ivory Coast, these cross reactions might be due to Fasciola gigantica and/or local schistosomes ( $S$. japonicum imperfectly crossed with $S$. haematobium and S. mansoni). Another African paragonimid species: P. uterobilateralis, might also be the cause of these cross reactions, although Slemenda et al. (1988) had reported that antibody detection for Paragonimus westermani did not allow that of other Paragonimus species. Further clinical and/or serological investigations in these 41 patients would be necessary to verify either of these both hypotheses.

Two arguments supporting the abovementioned first hypothesis were: $i$ ) the finding of Paragonimus spp. metacercariae in crabs bought at the local market of Divo, and ii) the crab-eating habits for 31 persons (out of the 41 patients with greater than 0.09 ODs). A serious risk of paragonimosis was thus currently present in the district of Divo and this interpretation is sustained by the fact that sold crustaceans came from Grand-Lahou, a town situated in the littoral of Ivory Coast, according to crab sellers. The same fact was already seen in Benin (West Africa) where crabs sold in local markets have been collected from Nigeria (Aka et al., 1999). To tackle this disease in Ivory Coast, the best solution would be the control of crab business in markets within the country.

Because of political and military instability prevailing in Ivory Coast since 2002, some patients have changed their residence and their eating habits, so that it is difficult to currently identify the zones of Paragonimus infection. Also, an outbreak of paragonimosis might occur, as that reported by Nwokolo (1972) in eastern Nigeria following the civil war. A surveillance of local anti-tuberculosis centres to detect Paragonimus-infected patients and a simultaneous control of local markets to limit selling of infected crustaceans would be effective to ascertain and control the extension of this anthropozoonosis in Ivory Coast.

\section{ACKNOWLEDGEMENTS}

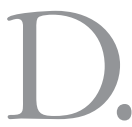

A. gratefully thanks the Japanese Society of Promotion of Science (JSPS) for its financial support (Grant ID n PE05033) and the Foreign Office of the University of Limoges for the rapport of mission. He is also grateful to Pr. Paron Dekumyoy for correcting the English text. 


\section{REFERENCES}

Adou-Bryn K.D., Ouhon J., Assoumou A., Kassi E.A., Kone M. \& Therizol-Ferly M. Champignons et parasites isolés à l'examen de 142 liquides d'aspiration bronchique à Abidjan, Côte d'Ivoire. Médecine d'Afrique Noire, 1999, 46, 362-365.

Aka K.E.D., Tchamra M.T., FAdiga D. \& YAPI A. Paragonimose pulmonaire: une cause d'hémoptysie. Afrique Bio-Médicale, 1996, 1, 29-31.

Aka N.A.D., Allabi A.C.E., Dreyfuss G., Kinde-Gazard D., Tawo L., Rondelaud D., Bouteille B., Avodé G., Anagonou S.Y., Gninafon M., Massougbodji A. \& Dumas M. Observations épidémiologiques sur le premier cas de paragonimose humaine et les hôtes intermédiaires potentiels de Paragonimus sp. au Bénin. Bulletin de la Société de Pathologie Exotique, 1999, 92, 191-194.

Blair D., Xu Z.B. \& Agatsuma T. Paragonimiasis and the genus Paragonimus. Advances in Parasitology, 1999, 42, 113-222.

Bosse D. Endémicité et parasitoses autochtones en Afrique noire : à propos d'un foyer insolite de distomatose pulmonaire en Côte d'Ivoire. $3^{\text {rd }}$ cycle Doctorate Thesis, Montpellier, 1984, $112 \mathrm{p}$.

Cho S.Y., LeE D.K., Kang S.Y. \& Sim S.I. An epidemiological study of human paragonimiasis by means of micro-ELISA. Korean Journal of Parasitology, 1983, 21, 246-256.

Coulibaly N., Cornet L., Doucet J. \& Loubière R. Paragonimose pulmonaire associée à une bilharziose en Côte d'Ivoire. Nouvelle Presse Médicale, 1975, 4, 886.

Moyou-Somo R., Kefié-Arrey C., Dreyfuss G. \& Dumas M. An epidemiological study of pleuropulmonary paragonimiasis among pupils in the peri-urban zone of Kumba town, Meme Division, Cameroon. BioMed Central Public Health, 2003, 3, 40-44.

Mukae H., Taniguchi H., Matsumoto N., Liboshi H., Ashitani J., MatsukURA S. \& NAwA Y. Clinicoradiologic features of pleuropulmonary Paragonimus westermani on Kyusyu Island, Japan. Chest, 2001, 120, 514-520.

Nwokolo C. Endemic paragonimiasis in eastern Nigeria. Clinical features and epidemiology of the recent outbreak following the Nigerian civil war. Tropical and Geographical Medicine, 1972, 24, 138-147.

Ripert C., Carrie J., Ambroise-Thomas P., Baecher R., Kum N.P. \& SAme-Еково A. Étude épidémiologique et clinique de la paragonimose au Cameroun. Résultats du traitement par le Niclofolan. Bulletin de la Société de Pathologie Exotique, 1981, 74, 319-331.

Slemenda S.B., Maddison S.E., Jong E.C. \& Moore D.D. Diagnosis of paragonimiasis by immunoblot. American Journal of Tropical Medicine and Hygiene, 1988, 39, 469-471.

Toscano C., Hai Y.S., Nunn P. \& Mott K.E. Paragonimiasis and tuberculosis, diagnostic confusion: a review of the literature. Tropical Diseases Bulletin, 1995, 92, R1-R27.

World Health Organization. Control of food-borne trematode infections. Report of a WHO Study Group. WHO Technical Report Series, no. 849. Geneva, 1995, 157 p.

Reçu le 29 août 2007 Accepté le 4 février 2008 